\title{
Prediction of Breach Peak Outflow and Failure Time Using Artificial Neural Network Approach
}

\author{
Mohammed T. Mahmoud, Ahmed H. Bukhary, Ahmed G. Ramadan, Muhammad A. Al-Zahrani \\ Department of Civil and Environmental Engineering, King Fahd University of Petroleum and Minerals \\ Dhahran 31261, Saudi Arabia \\ g201408660@kfupm.edu.sa; g201402400@kfupm.edu.sa; g201409700@kfupm.edu.sa; mzahrani@kfupm.edu.sa
}

\begin{abstract}
Prediction of breach peak outflow and time of failure with appreciable level of accuracy is of substantial importance to avoiding potential life loss, minimising damage and consequently financial losses in the downstream floodplain. The damage is certain when a dam fails; however, the magnitude of it cannot be evaluated a head of time. This paper proposes the use of Artificial Neural Network (ANN) approach to predict the peak outflow and failure time of breached earthen dams. Several parameters such as the type of dam, height and volume of water behind the dam, erodibility of dam materials, and the mode of failure are used for the estimation purpose. Historical datasets of dam failures are employed in the training process of various ANN structures. The reliability of the proposed ANN approach was evaluated by means of Correlation coefficient (CC) and the Root Mean Square Error (RMSE). Subsequently, a comparison is drawn between ANN approach and popular regression models. The ANN approach is found to be considerably more reliable than regression analysis.
\end{abstract}

Keywords: Artificial Neural Network, Peak outflow, ANN, Breached earthen dams, Time of failure

\section{Introduction}

Dams and their associated engineering practice are considered to be a main part of the story of civilisation. The significant contribution which dams have made towards the rise of civilisations is documented in a number of records of ancient lands [1]. The cradles of civilisation in Babylonia, Egypt, India, Persia and the Far East are nothing but a compelling evidence of the substantial services which dams have been providing during the last 50 centuries. Essential benefits such as water supply, flood control, irrigation, and hydropower generation are some good examples of such contribution.

Earthen dams are one of the oldest types of dams and their construction is still being warmly received in different parts of the world. The number of earthen dams in Iran for instance, is outnumbering those of other dams' types. At the other end of the spectrum however, the possibility of failure to take place in earthen dams is appreciably higher than in other types [2]. Huge financial loss apart from deaths can be brought about, due to dam failure. The latter results in release of an immense volume of water, which in turn, creates huge waves in downstream. The causes of earthen dam failure are numerous, and the exact failure mode is sometimes difficult to determine.

[3] reported that inadequate spillway capacity which causes overtopping of the dam, constitutes about one-third of earthen dam failures. On the other hand, piping as a result of concentrated seepage have been crudely considered the cause of another one-third of earthen dam failures. The remaining third of dam failures are attributed to sliding of the embankment, foundation settlement, and inadequate measures of protection against wave action. Hence, prediction of dam failure and the subsequent danger is of high significance to avoid financial and more importantly life losses by means of proper design and preparation of good emergency action plans.

Since 1970s the science of dam breach analysis has been evolving within the scope of minimising the potential damage and loss of life associated with dam failures. Hydraulic analysis of dam breach includes two main steps, the prediction of reservoir outflow hydrograph and the routing of that hydrograph through the downstream valley. The first step can further be subdivided into predicting the breach characteristics (e.g., shape, depth, width, rate of breach formation), and routing the reservoir storage and inflow through the breach [4]. 
Dam break analysis can be performed with the aid of a multitude of available tools. Refined estimates of certain geometric and temporal characteristics as inputs are required in dam-break analysis programs. The outputs of the model encompass water surface elevation, velocity of the flow, and flow depth. Such details may serve to evaluate the magnitude of the potential damage which the breach has brought about. Models such as National Weather Service (NWS) DamBreak Flood Forecasting Model (DAMBRK), the U.S. Army Corps of Engineers Hydrologic Engineering Centre Flood Hydrograph Package (HEC-1), and the NWS Simplified Dam-Break Flood Forecasting Model (SMPDBK) are compared in a paper published by [5].

An alternative approach for estimation of the breach peak outflow is through developing regression relations as a function of dam geometric parameters based on case-study information [6]. A minimum figure of 16 regression expressions for estimation of breach peak outflow of earthen dams have been developed since 1977. Nonetheless, it should be pointed out that limited database of case studies was employed to derive these relationships, and therefore, they offer a moderate level of confidence.

One of the most comprehensive databases of dam breach case studies was compiled by [7], [8]. His study reviewed regression expressions developed throughout 1977 to 1995. The focus of initial efforts was on determining height of dam and dam volume/storage relations. The database was then broadened by [9] who conducted a review of the available regression relations for estimating breach peak outflow [10].

\subsection{Artificial Neural Network}

Artificial Neural Network (ANN) is one of the most powerful classifiers that describes input/output relationships. The role which the classifier was meant to serve is the imitation of the human brain acquisition of knowledge through learning within neuron connection strengths. Synaptic weights of ANN are usually trained so that a certain input leads to a specific targeted output. In other words, comparing the targeted and the actual output until the network output matches the targeted

one. Should that happen, training and neural network weights may now be tested with new data Multi-layer Perceptron [11].

Considering the numerous restrictive assumptions of regression analysis, ANNs can be good alternative when the target is predicting peak outflow and time of failure of breached dams, due to the nonlinear nature of their structure along with the flexibility in their application. Hastie (2001) [12] demonstrated that ANNs are vastly succeeded approximators of multitude of complex functions.

Some researchers investigated several ANN algorithms so as to settle upon the best one that results in the most accurate estimation of peak outflow. Hooshyaripor (2015) [13] used two algorithms to train the ANN networks and then developed and compared 20 different models with each other. They concluded that the least means square (LMS) training function resulted in the highest correlation coefficient and lowest RMSE [14].

Technical publications which compare the performance of different ANN models with regression techniques are limited. Therefore, this paper is written within this scope.

\section{Methodology}

The objective of this paper is to develop a neural network model which has the ability to predict the breach peak outflow and the time of failure of earthen dams with appreciable accuracy over the conventional regression analysis.

The process of predicting breach peak outflow and time of failure using Artificial Neural Network can be divided to three main stages: data acquisition, prediction using ANN model, and application of ANN. Next, a comparison between the results obtained using ANN and those achieved by employing recent selected regression models will be drawn to assess the reliability of the proposed ANN approach.

\subsection{Data Acquisition (Stage 1)}

The database adopted for analysis was collected from the literature. Specifically from database reported by [9] and [15]. The former compiled database that contained hydrologic and geometric variables from 87 breach case studies, while the latter compiled his database from different sources [7], [16]-[19]. Tables 1 and 2 summarise the information and details of dam failure case studies which represent the analysis database used in this paper. 


\subsection{Artificial Neural Network Prediction (Stage 2)}

\subsubsection{Multi-Layer Perceptrons}

Multi-Layer Perceptrons (MLPs) is one of the most common models of the artificial neural network. It implements the supervised training methods to train the network and is hierarchically structured of perceptrons. Layers which commonly form MLPs are input layer, hidden layer, and output layer. The complications associated with training such network with multiple layers is apparently higher than with a single perceptron. When an error is encountered, locating the error's source is not easy due to the different nodes of each layer. Moreover, easiness does not lend itself to the process of adjusting the weights according to their contribution. Using the back-propagation algorithm which is a generalisation of the least-meansquare (LMS) algorithm can solve all of the problems stated earlier. The algorithm finds the effect of the weights of the network. Various weights that use feed-forward connections link the nodes in the input and hidden layers. The mean square error (MSE) is computed using all training patterns of the calculated and target outputs as follows:

$$
M S E=\frac{1}{2} \sum_{j=1}^{m} \sum_{i=1}^{k}\left(T_{i j}-O_{i j}\right)^{2}
$$

In order to minimise the total mean square error between the actual output and the targeted one, the back-propagation algorithm employs iterative gradient technique. Some random small weights are set to initialise the training process. Training data are repeatedly presented to the neural network and the weights are adjusted until a reduced acceptable value of MSE is reached [11]. The general concept of ANN discussed earlier is shown in Figure 1.

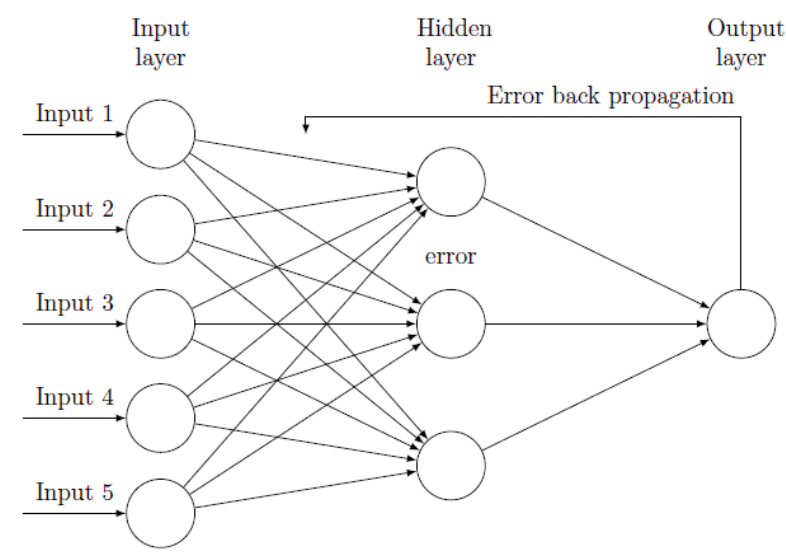

Fig. 1: Systematic diagram of ANN and its error back propagation architecture [20].

\subsubsection{Application of ANN}

In this stage, four models were created using historical database. The first model compares ANN technique with two recent regression approaches which are used to predict the breach peak outflow, [3] and [9] "Volume and height expression". In this model the volume and the height of the water behind the dam were used as input data to ANN model, while the second Model used Dam factor $(\mathrm{VH})$ as an input to fit a good relation to predict breach peak outflow. The third model was used to compare the breach peak outflow prediction using [15] regression model and ANN approach. [15] tried to enhance the prediction of all breach parameters by using multi-variable regression analysis. In addition, they used most of the failed dams' characteristics. In this paper, the authors used the height of the dam, reservoir water volume, dam type, material erodibility, and failure mode.

On the other hand, the fourth model constructed to evaluate the prediction of the time of failure. [15] formula which shows good correlation compared to the old methods was used for comparing results with the developed ANN model when estimating the time of failure. 


\subsection{Comparison of Relationships (Stage 3)}

The comparison between ANN model and other selected models is shown in Table 3. The comparison between prediction models was performed using two statistical parameters; Correlation coefficient (CC) and Root-mean-square Error (RMSE). The Correlation coefficient (CC) is usually used to describe the arrangement of the data and how datasets are correlated; however, Root-mean-square Error (RMSE) is used to describe the bias and error of observed data compared with predicted data. To have a good judgment, regression expressions and Artificial Neural Network approach (ANN) were applied on the same historical database which are shown in Tables 1 and 2. The Correlation coefficient (CC) and Rootmean-square Error (RMSE) are found using the following equations:

$$
\begin{gathered}
R M S E=\sqrt{\frac{1}{n} \sum_{i=1}^{n}\left(X_{i}-Y_{i}\right)^{2}} \\
R^{2}=\frac{\frac{1}{n} \sum_{i=1}^{n}\left(X_{i}-\bar{X}\right)\left(Y_{i}-\bar{Y}\right)}{\sigma_{x} \sigma_{y}}
\end{gathered}
$$

\section{Results and Discussion}

In order to have a better understanding of the results, two statistical measurements ( $\mathrm{R}^{2}$ and RMSE) were applied to evaluate the reliability of the approach and compare between each model and the most popular prediction methods which are using the same parameters to estimate breach peak outflow and time of failure. Overall, the results have proven that ANN approach tends to have a better prediction than traditional regression models. All results and the parameters used to construct each model are illustrated in Table 3.

The first model is constructed using Table 2 database, with water volume $(\mathrm{V})$ and water height $\left(\mathrm{h}_{\mathrm{w}}\right)$ as input parameters. The correlation coefficient for ANN approach is found to be $\mathrm{R}^{2}=0.944$ while the other approaches Froehlich (1995) and Pierce et al. (2010) have $\mathrm{R}^{2}=0.598$ and 0.637, respectively (Figure 2). These results illustrate that the predicted results which were generated using ANN approach are more correlated to field measurements. In addition, the other parameter Root-mean-square Error (RMSE) supported the same conclusion. The RMSE for ANN approach is 2909 which is extremely less than the other two methods 8029 and 7511 for Froehlich (1995) and Pierce et al. (2010), respectively (Table 3).

Similarly, the second and third model shows the same interpretation with correlation coefficient of 0.94 and 0.92 , respectively. Moreover, RMSE shows less values than the other regression models as presented in Table 3.

Figures 3 and 4 illustrate a comparison between the correlation coefficient of ANN and selected regression models for prediction of breach peak outflow.

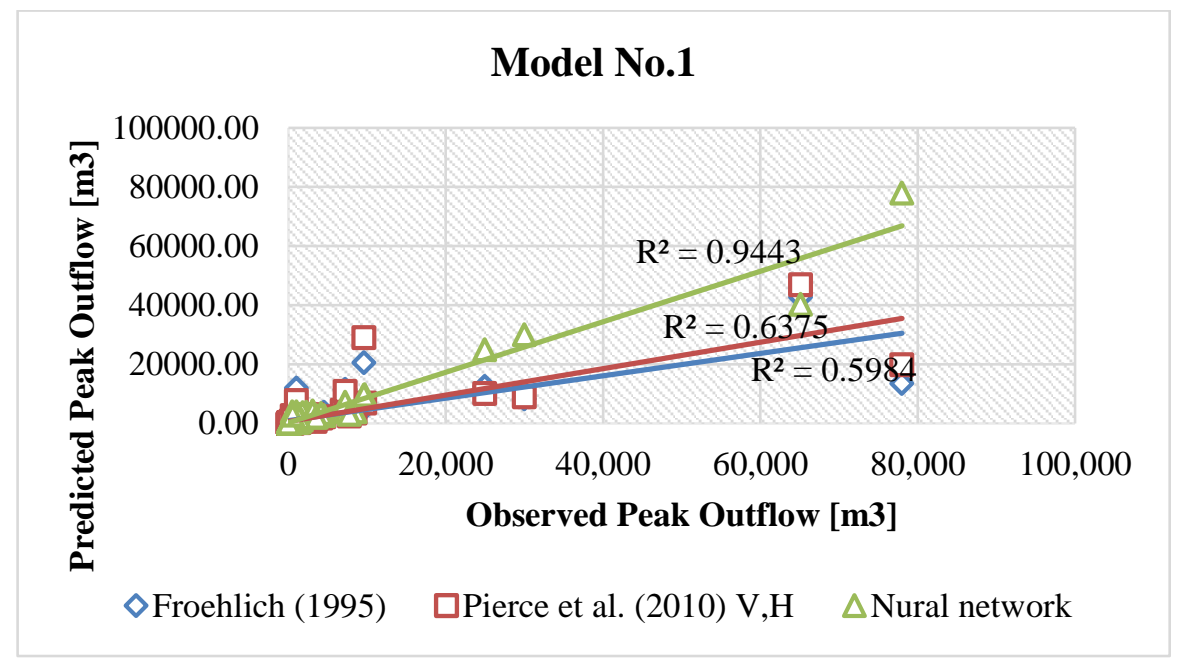

Fig. 2: Peak outflow prediction using ANNs (model-1) and its correlation coefficient in compare with Froehlich (1995) [3] and Pierce et al. (2010) [9] models. 


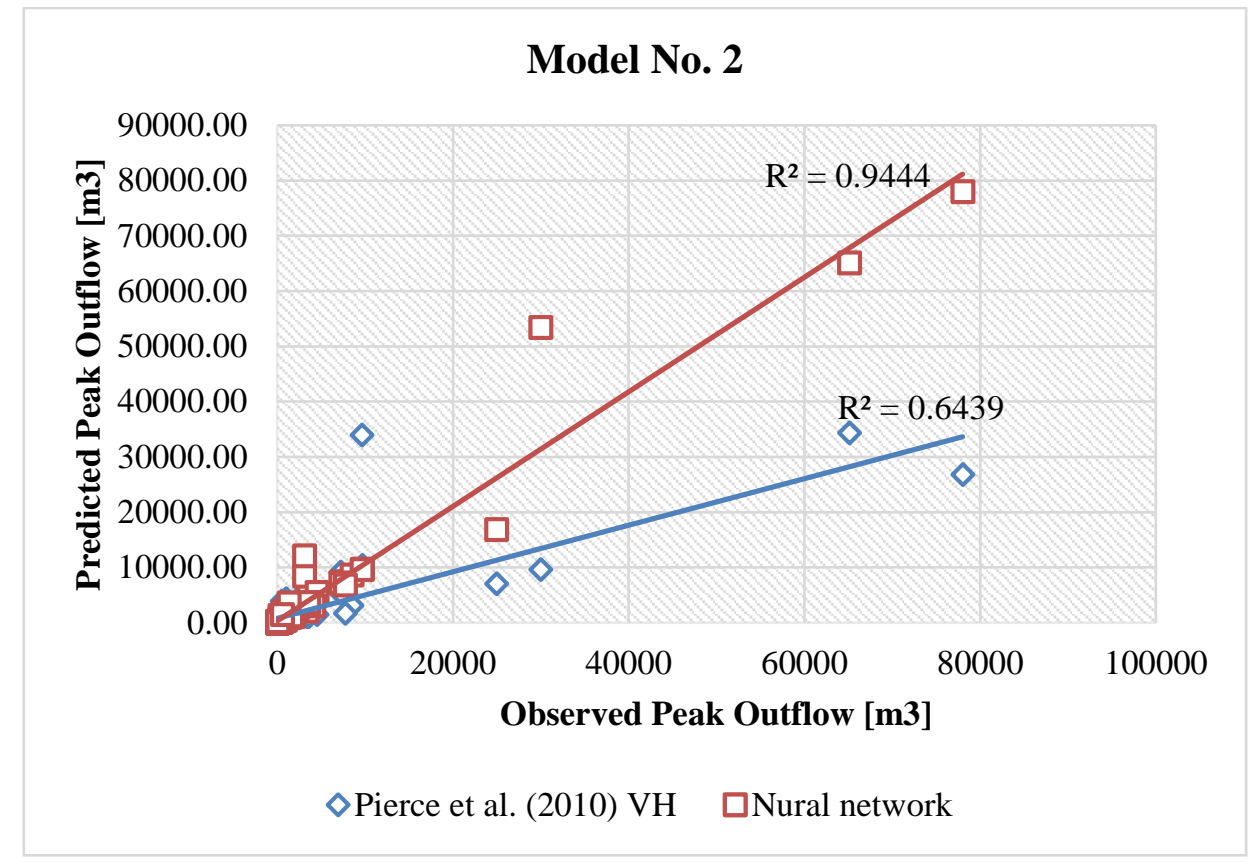

Fig. 3: Peak outflow prediction using ANNs (model-2) and its correlation coefficient in compare with Pierce et al. (2010) [10] model.

Finally, the fourth model was constructed using Xu and Zhang (2009) [15] database to predict the breach time of failure. This model has shown to be more correlated to measured data. Also, compared with Xu and Zhang (2009) [15], ANNs approach has proven its efficiency and reliability over the regression models. The results can be noticed in Figure 5 and Table 3. The reader may notice that ANN approach has higher CC and low RMSE.

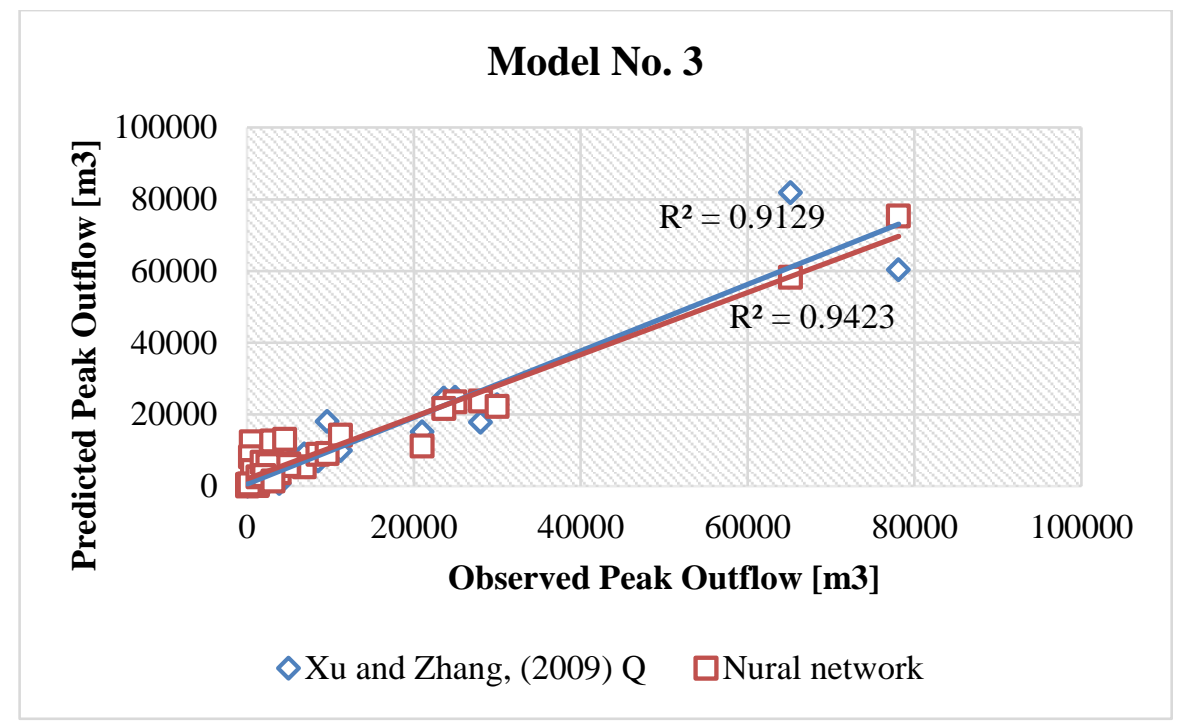

Fig. 4: Peak outflow prediction using ANNs (model-3) and its correlation coefficient in comparison with Xu and Zhang, (2009) [15] model. 


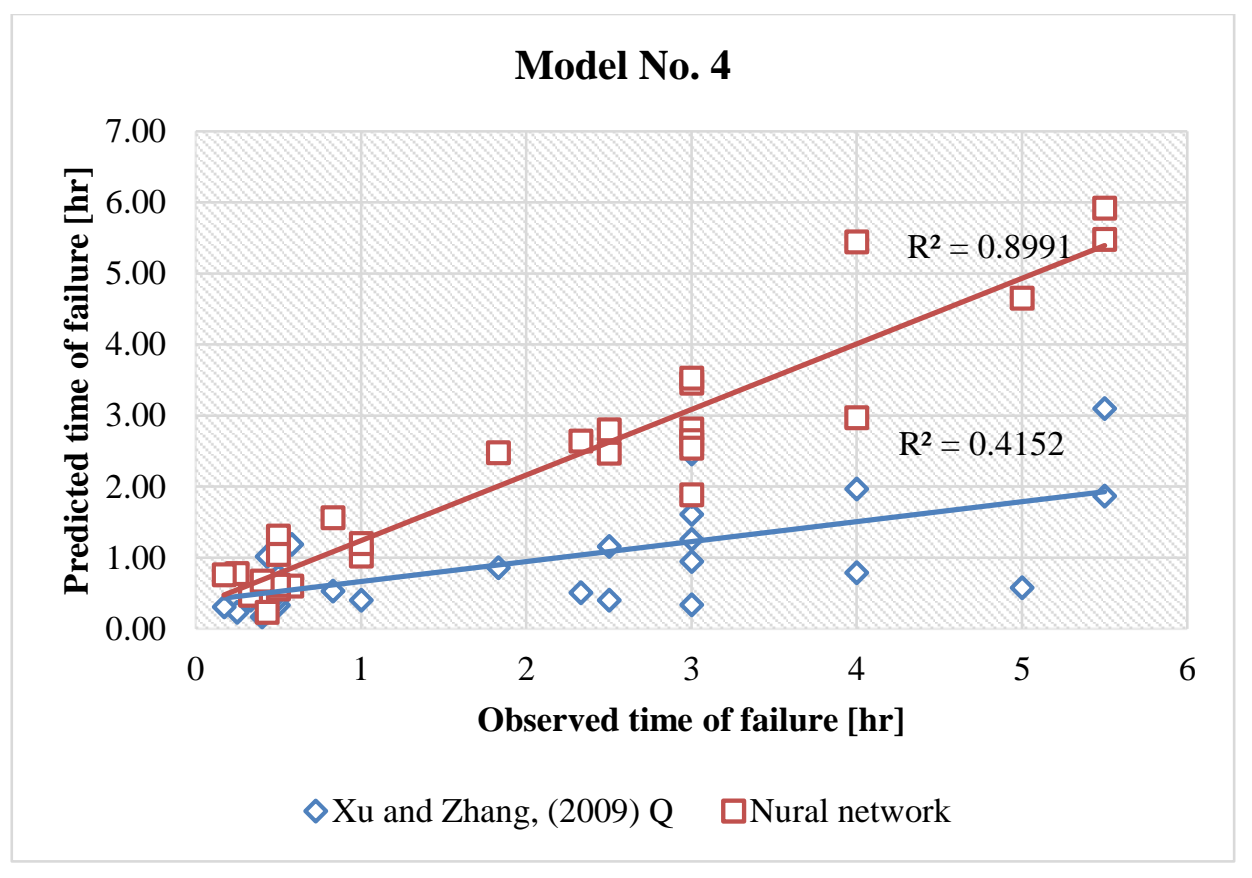

Fig. 5: Peak outflow prediction using ANNs (model-4) compared with Xu and Zhang (2009) [15] model.

\section{Conclusion}

Recently, ANNs techniques have made a major contribution towards data modelling, especially that deals with uncertain data estimation. Generally, ANNs models are more reliable in presenting the relationship between the variables and the target. In this study, three models for prediction of breach peak outflow and one model for prediction of time of failure were developed using ANNs.

The reliability of the proposed ANNs technique was evaluated by means of two statistical parameters; Correlation coefficient (CC) and the Root Mean Square Error (RMSE). The results show that the correlation coefficients of all ANNs models are by far found to be higher than their counterparts from regression analysis. Moreover, RMSE of ANNs models estimated at appreciably lower values in comparison with the regression models.

Based upon the previous discussion presented earlier, it can be concluded that utilisation of ANN in predicting breach peak outflow and time of failure is highly recommended.

\section{Recommendations}

Application of these theories have demonstrated their effectiveness in predicting earthen dams breach parameters and have given better results in dam break analysis studies. Saudi Arabia's dams need to be assessed using this approach so as predict the peak outflow in order to study risk analysis for these dams. Additionally, predicting breach time of failure using this approach can enhance the emergency plans for large dams in the Kingdom, and subsequently, lead to save lives and property.

\section{Acknowledgement}

The support of the Civil and Environmental Engineering Department of King Fahd University of Petroleum and Minerals is highly acknowledged. 
Table 1: Locations and dam's characteristics (Pierce et al. 2010).

\begin{tabular}{|c|c|c|c|c|c|c|c|c|c|c|c|}
\hline No. & Site & $\begin{array}{c}\mathrm{H} \\
(\mathrm{m})\end{array}$ & $\mathrm{V}\left(\mathrm{m}^{3}\right)$ & $\begin{array}{c}\text { Dam } \\
\text { factor VH }\end{array}$ & Qp & No. & Site & $\mathrm{H}(\mathrm{m})$ & $\mathrm{V}\left(\mathrm{m}^{3}\right)$ & $\begin{array}{c}\text { Dam factor } \\
\text { VH }\end{array}$ & Qp \\
\hline 1 & $\begin{array}{l}\text { HR Wallingford } \\
\text { Test 14, U.K. }\end{array}$ & 0.6 & 245 & 147 & 0.28 & 31 & $\begin{array}{l}\text { Upper Clear } \\
\text { Boggy, Okla. }\end{array}$ & 6.1 & 863000 & 5264300 & 70.79 \\
\hline 2 & $\begin{array}{l}\text { HR Wallingford } \\
\text { Test 10, U.K. }\end{array}$ & 0.6 & 245 & 147 & 0.31 & 32 & Lily Lake, Colo. & 3.35 & 92500 & 309875 & 71 \\
\hline 3 & $\begin{array}{l}\text { HR Wallingford } \\
\text { Test 11, U.K. }\end{array}$ & 0.6 & 245 & 147 & 0.34 & 33 & $\begin{array}{l}\text { Field Test 2-2, } \\
\text { Norway }\end{array}$ & 5 & 35900 & 179500 & 74 \\
\hline 4 & $\begin{array}{l}\text { HR Wallingford } \\
\text { Test } 15, \text { U.K. }\end{array}$ & 0.6 & 245 & 147 & 0.35 & 34 & Frankfurt, Germany & 8.23 & 352000 & 2896960 & 79 \\
\hline 5 & $\begin{array}{l}\text { HR Wallingford } \\
\text { Test 16, U.K. }\end{array}$ & 0.6 & 245 & 147 & 0.43 & 35 & Ireland No. 5, Colo. & 3.81 & 160000 & 609600 & 110 \\
\hline 6 & $\begin{array}{l}\text { HR Wallingford } \\
\text { Test } 12 \text {, U.K. }\end{array}$ & 0.6 & 245 & 147 & 0.53 & 36 & $\begin{array}{l}\text { Field Test 1-2, } \\
\text { Norway }\end{array}$ & 5.9 & 63000 & 371700 & 113 \\
\hline 7 & $\begin{array}{l}\text { HR Wallingford } \\
\text { Test 17, U.K. }\end{array}$ & 0.6 & 245 & 147 & 0.61 & 37 & Prospect, Colo. & 1.68 & 3540000 & 5947200 & 116 \\
\hline 8 & $\begin{array}{l}\text { USDA-ARS Test } \\
\# 6 \text {, Okla. }\end{array}$ & 1.5 & 5190 & 7785 & 1.3 & 38 & $\begin{array}{l}\text { South Fork } \\
\text { Tributary, Pa. }\end{array}$ & 1.83 & 3700 & 6771 & 122 \\
\hline 9 & $\begin{array}{l}\text { USDA-ARS Test } \\
\# 3 \text {, Okla. }\end{array}$ & 2.29 & 4900 & 11221 & 1.8 & 39 & $\begin{array}{l}\text { Site Y-30-95, } \\
\text { Miss. }\end{array}$ & 7.47 & 142000 & 1060740 & 144.42 \\
\hline 10 & $\begin{array}{l}\text { Site Y-36-25, } \\
\text { Miss. }\end{array}$ & 9.75 & 35800 & 349050 & 2.12 & 40 & $\begin{array}{l}\text { Lower Reservoir, } \\
\text { Maine }\end{array}$ & 9.6 & 604000 & 5798400 & 157.44 \\
\hline 11 & $\begin{array}{l}\text { USDA-ARS Test } \\
\# 4 \text {, Okla. }\end{array}$ & 1.5 & 5090 & 7635 & 2.3 & 41 & $\begin{array}{l}\text { Field Test 3-3, } \\
\text { Norway }\end{array}$ & 4.3 & 22000 & 94600 & 170 \\
\hline 12 & $\begin{array}{l}\text { USDA-ARS Test } \\
\# 7, \text { Okla. }\end{array}$ & 2.13 & 4770 & 10160.1 & 4.2 & 42 & $\begin{array}{l}\text { Field Test 2-3, } \\
\text { Norway }\end{array}$ & 6 & 67300 & 403800 & 174 \\
\hline 13 & Peter Green, N.H. & 3.96 & 19700 & 78012 & 4.42 & 43 & $\begin{array}{l}\text { Field Test 1-1, } \\
\text { Norway }\end{array}$ & 6.1 & 73000 & 445300 & 190 \\
\hline 14 & $\begin{array}{l}\text { Stevens Dam, } \\
\text { Mont. }\end{array}$ & 4.27 & 78900 & 336903 & 5.92 & 44 & $\begin{array}{l}\text { Field Test 1-3, } \\
\text { Norway }\end{array}$ & 5.9 & 63000 & 371700 & 242 \\
\hline 15 & $\begin{array}{l}\text { USDA-ARS Test } \\
\# 1 \text {, Okla. }\end{array}$ & 2.29 & 4900 & 11221 & 6.5 & 45 & Lake Latonka, Pa. & 6.25 & 4090000 & 25562500 & 290 \\
\hline 16 & $\begin{array}{l}\text { Cherokee Sandy, } \\
\text { Okla. }\end{array}$ & 5.18 & 444000 & 2299920 & 8.5 & 46 & $\begin{array}{l}\text { Horse Creek \#2, } \\
\text { Colo. }\end{array}$ & 12.5 & 4800000 & 60000000 & 311.49 \\
\hline 17 & $\begin{array}{l}\text { Upper Red Rock, } \\
\text { Okla. }\end{array}$ & 4.57 & 247000 & 1128790 & 8.5 & 47 & $\begin{array}{l}\text { Lower Latham, } \\
\text { Colo. }\end{array}$ & 5.79 & 7080000 & 40993200 & 340 \\
\hline 18 & Break Neck Run & 7 & 49000 & 343000 & 9.2 & 48 & Sandy Run, Pa. & 8.53 & 56700 & 483651 & 435 \\
\hline 19 & Colonial \#4, Pa. & 9.91 & 38200 & 378562 & 14.16 & 49 & $\begin{array}{l}\text { Puddingstone, } \\
\text { Calif. }\end{array}$ & 15.2 & 617000 & 9378400 & 480 \\
\hline 20 & $\begin{array}{l}\text { Caney Coon } \\
\text { Creek, Okla. }\end{array}$ & 4.57 & 1320000 & 6032400 & 16.99 & 50 & $\begin{array}{l}\text { Davis Reservoir, } \\
\text { Calif. }\end{array}$ & 11.58 & 58000000 & $6.72 \mathrm{E}+08$ & 510 \\
\hline 21 & Murnion, Mont. & 4.27 & 321000 & 1370670 & 17.5 & 51 & Lawn Lake, Colo. & 6.71 & 798000 & 5354580 & 510 \\
\hline 22 & Haymaker, Mont. & 4.88 & 370000 & 1805600 & 26.9 & 52 & Goose Creek, S.C. & 1.37 & 10600000 & 14522000 & 565 \\
\hline 23 & North Branch, Pa. & 5.49 & 22200 & 121878 & 29.4 & 53 & $\begin{array}{l}\text { Wheatland } \\
\text { Reservoir \#1, Wyo. }\end{array}$ & 12.19 & 11500000 & $1.4 \mathrm{E}+08$ & 566.34 \\
\hline 24 & Owl Creek, Okla. & 4.88 & 120000 & 585600 & 31.15 & 54 & Fred Burr, Mont. & 10.2 & 750000 & 7650000 & 654 \\
\hline 25 & $\begin{array}{l}\text { Middle Clear } \\
\text { Boggy, Okla. }\end{array}$ & 4.57 & 444000 & 2029080 & 36.81 & 55 & Kelly Barnes, Ga. & 11.3 & 777000 & 8780100 & 680 \\
\hline 26 & $\begin{array}{l}\text { Site Y-31A-5, } \\
\text { Miss. }\end{array}$ & 9.45 & 386000 & 3647700 & 36.98 & 56 & DMAD, Utah & 8.8 & 19700000 & $1.73 \mathrm{E}+08$ & 793 \\
\hline 27 & $\begin{array}{l}\text { Little Wewoka, } \\
\text { Okla. }\end{array}$ & 9.45 & 987000 & 9327150 & 42.48 & 57 & Butler, Ariz. & 7.16 & 000 & 0800 & 810 \\
\hline 28 & $\begin{array}{l}\text { Dam Site \#8, } \\
\text { Miss. }\end{array}$ & 4.57 & 870000 & 3975900 & 48.99 & 58 & $\begin{array}{l}\text { French Landing, } \\
\text { Mich. }\end{array}$ & 8.53 & 3870000 & 33011100 & 929 \\
\hline 29 & Otto Run & 5.79 & 7400 & 42846 & 60 & 59 & $\begin{array}{l}\text { Euclides de Cunha, } \\
\text { Brazil }\end{array}$ & 58.22 & 13600000 & $7.92 \mathrm{E}+08$ & 1020 \\
\hline 30 & Boydstown, $\mathrm{Pa}$. & 8.96 & 358000 & 3207680 & 65.13 & 60 & Laurel Run, $\mathrm{Pa}$. & 14.1 & 555000 & 7825500 & 1050 \\
\hline
\end{tabular}


Table 2: List of dam failure case studies (Xu and Zhang 2009).

\begin{tabular}{|c|c|c|c|c|c|c|c|c|c|c|}
\hline No. & Dam name & Location & Type & $\mathrm{H}$ & Erodibility & Mode & $\mathrm{Vw}$ & $\mathrm{Hw}$ & Q & tf \\
\hline 1 & Apishapa & United States & HD & 34.1 & $\mathrm{HE}$ & $\mathrm{P}$ & 22.2 & 28 & 6850 & 2.5 \\
\hline 2 & Banqiao & China & $\mathrm{DC}$ & 24.5 & $\mathrm{HE}$ & $\mathrm{O}$ & 607.5 & 31 & 78100 & 5.5 \\
\hline 3 & Bayi & China & HD & 30 & $\mathrm{ME}$ & $\mathrm{P}$ & 23 & 28 & 5000 & - \\
\hline 4 & Castlewood & United States & $\mathrm{DC}$ & 21.3 & $\mathrm{ME}$ & $\mathrm{O}$ & 6.17 & 21.6 & 3570 & - \\
\hline 5 & Chenying & China & $\mathrm{HD}$ & 12 & $\mathrm{ME}$ & $\mathrm{O}$ & 5 & 12 & 1200 & 1.83 \\
\hline 6 & Danghe & China & $\mathrm{DC}$ & 46 & LE & $\mathrm{O}$ & 10.7 & 24.5 & 2500 & 3 \\
\hline 7 & DavisReservior & United States & FD & 11.9 & ME & $\mathrm{P}$ & 58 & 11.58 & 510 & - \\
\hline 8 & Dells & United States & - & 18.3 & $\mathrm{HE}$ & $\mathrm{O}$ & 13 & 18.3 & 5440 & 0.67 \\
\hline 9 & Dongchuankou & China & $\mathrm{HD}$ & 31 & $\mathrm{HE}$ & $\mathrm{O}$ & 27 & 31 & 21000 & - \\
\hline 10 & Elk City & United States & $\mathrm{DC}$ & 9.1 & $\mathrm{ME}$ & $\mathrm{O}$ & 1.18 & 9.44 & - & 0.83 \\
\hline 11 & Frankfurt & Germany & $\mathrm{HD}$ & 9.8 & LE & $\mathrm{P}$ & 0.352 & 8.23 & 79 & 2.5 \\
\hline 12 & French Landing & United States & $\mathrm{HD}$ & 12.2 & $\mathrm{HE}$ & $\mathrm{P}$ & 3.87 & 8.53 & 929 & 0.58 \\
\hline 13 & Frenchman Dam & United States & $\mathrm{HD}$ & 12.5 & $\mathrm{ME}$ & $\mathrm{P}$ & 16 & 10.8 & 1420 & 3 \\
\hline 14 & Frias & Argentina & FD & 15 & $\mathrm{ME}$ & $\mathrm{O}$ & 0.25 & 15 & 400 & 0.25 \\
\hline 15 & Gouhou & China & FD & 71 & LE & $\mathrm{P}$ & 3.18 & 44 & 2050 & 2.33 \\
\hline 16 & Grand Rapids & United States & $\mathrm{DC}$ & 7.6 & ME & $\mathrm{O}$ & 0.255 & 7.5 & - & 0.5 \\
\hline 17 & Hatfield & United States & - & 6.8 & $\mathrm{HE}$ & $\mathrm{O}$ & 12.3 & 6.8 & 3400 & 2 \\
\hline 18 & Hell Hole & United States & - & 67.1 & $\mathrm{ME}$ & $\mathrm{P}$ & 30.6 & 35.1 & 7360 & - \\
\hline 19 & Horse Creek & United States & FD & 12.2 & $\mathrm{ME}$ & $\mathrm{P}$ & 12.8 & 7.01 & 3890 & 3 \\
\hline 20 & Huqitang & China & $\mathrm{HD}$ & 9.9 & LE & $\mathrm{P}$ & 0.424 & 5.1 & 50 & 4 \\
\hline 21 & Johnstown & United States & $\mathrm{ZD}$ & 38.1 & $\mathrm{ME}$ & $\mathrm{O}$ & 18.9 & 24.6 & 8500 & - \\
\hline 22 & Kelly Barnes & United States & HD & 11.6 & HE & $\mathrm{O}$ & 0.777 & 11.3 & 680 & 0.5 \\
\hline 23 & Kodaganar & India & $\mathrm{HD}$ & 11.5 & $\mathrm{ME}$ & $\mathrm{O}$ & 12.3 & 11.5 & 1280 & - \\
\hline 24 & Lake Frances & United States & $\mathrm{HD}$ & 15.2 & ME & $\mathrm{P}$ & 0.789 & 14 & - & 1 \\
\hline 25 & Lake Latonka & United States & $\mathrm{HD}$ & 13 & $\mathrm{ME}$ & $\mathrm{P}$ & 4.09 & 6.25 & 290 & 3 \\
\hline 26 & Lijiaju & China & HD & 25 & ME & $\mathrm{O}$ & 1.14 & 25 & 2950 & - \\
\hline 27 & Little Deer Creek & United States & $\mathrm{HD}$ & 26.2 & $\mathrm{HE}$ & $\mathrm{P}$ & 1.36 & 22.9 & 1330 & 0.33 \\
\hline 28 & Liujiatai & China & DC & 35.9 & $\mathrm{ME}$ & $\mathrm{O}$ & 40.54 & 35.9 & 28000 & - \\
\hline 29 & Lower Two Medicine & United States & $\mathrm{HD}$ & 11.3 & $\mathrm{HE}$ & $\mathrm{O}$ & 19.6 & 11.3 & 1800 & - \\
\hline 30 & Mahe & China & $\mathrm{HD}$ & 19.5 & $\mathrm{HE}$ & $\mathrm{O}$ & 23.4 & 19.5 & 4950 & - \\
\hline 31 & Mammoth & United States & $\mathrm{DC}$ & 21.3 & $\mathrm{ME}$ & $\mathrm{O}$ & 13.6 & 21.3 & 2520 & 3 \\
\hline 32 & Martin Cooling Pond Dike & United States & - & 10.4 & $\mathrm{HE}$ & $\mathrm{P}$ & 136 & 8.53 & 3115 & - \\
\hline
\end{tabular}


Table 3: Comparision results between ANN approch and selected regression models usin CC and RMSE.

\begin{tabular}{|c|c|c|c|c|}
\hline ANN Model No. & Parameters used & Methods in comparison & $\mathrm{R}^{2}$ & RMSE \\
\hline \multicolumn{5}{|c|}{ Prediction of breach peak outflow } \\
\hline \multirow{3}{*}{1} & \multirow{3}{*}{$\begin{array}{l}\text { Volume of water } \\
\text { Height of Water }\end{array}$} & Froehlich (1995) & 0.598 & 8029.087 \\
\hline & & Pierce et al. (2010) & 0.638 & 7511.656 \\
\hline & & ANN model No. 1 & 0.944 & 2909.575 \\
\hline \multirow{2}{*}{2} & \multirow[t]{2}{*}{ Dam Factor } & Pierce et al. (2010) & 0.644 & 7891.123 \\
\hline & & ANN model No. 2 & 0.944 & 3031.324 \\
\hline \multirow{2}{*}{3} & \multirow[t]{2}{*}{ All dam Characteristics } & $\mathrm{Xu}$ and Zhang, (2009) & 0.913 & 5183.012 \\
\hline & & ANN model No. 3 & 0.942 & 4475.356 \\
\hline \multicolumn{5}{|c|}{ Prediction of time of failure } \\
\hline \multirow{2}{*}{4} & \multirow[t]{2}{*}{ All dam Characteristics } & $\mathrm{Xu}$ and Zhang, (2009) & 0.415 & 1.717 \\
\hline & & ANN model No. 4 & 0.899 & 0.550 \\
\hline
\end{tabular}

\section{References}

[1] R. B. Jansen, "Dams from the Beginning," no. Part I, pp. 1-57, 1980.

[2] A. K. Shahraki and M. Moharrampour, "Estimating Earthen Dam-Breach Parameters," no. 2552 m.

[3] D. C. Froehlich, "Peak Outflow from Breached Embankment Dam," J. Water Resour. Plan. Manag., vol. 121, no. 5766, pp. 90-97, 1995.

[4] T. L. Wahl, "Predicting Embankment Dam Breach Parameters-A Needs Assessment," Energy Water Sustainable Dev., pp. 48-53, 1997.

[5] R. A. Wurbs, "Dam-Breach Flood Wave Models," J. Hydrol. Eng. Eng., vol. 113, no. 1, pp. 29-46, 1987.

[6] C. I. Thornton, M. W. Pierce, and S. R. Abt, "Enhanced Predictions for Peak Outflow from Breached Embankment Dams," J. Hydrol. Eng., vol. 16, no. 1, pp. 81-88, 2011.

[7] T. Wahl, "Prediction of Embankment Dam Breach Parameters-A literature review and needs assessment," Rep. No. DSO-98-004, Denver., 1998.

[8] T. L. Wahl, "Uncertainty of Predictions of Embankment Dam Breach Parameters," J. Hydraul. Eng., vol. 130, no. 5, pp. 389-397, 2004.

[9] M. W. Pierce, C. I. Thornton, and S. R. Abt, "Predicting Peak Outflow from Breached Embankment Dams," J. Hydrol. Eng., vol. 15, no. 5, pp. 338-349, 2010.

[10] M. W. Pierce, C. I. Thornton, and S. R. Abt, "Predicting Peak Outflow from Breached Embankment Dams," $J$. Hydrol. Eng., vol. 15, no. 5, pp. 338-349, 2010.

[11] J. Zupan, "Introduction to Artificial Neural Network (ANN) Methods: what they and how to use them," Acta Chim. Slov., pp. 327-327, 1994.

[12] T. J. Hastie, R. J. Tibshirani, and J. H. Friedman, "The elements of statistical learning : data mining, inference, and prediction," Springer Ser. Stat., pp. 1-2, 2009.

[13] F. Hooshyaripor, A. Tahershamsi, and K. Behzadian, "Estimation of peak outflow in dam failure using neural network approach under uncertainty analysis," Water Resour., vol. 42, no. 5, pp. 721-734, 2015.

[14] F. Hooshyaripor, A. Tahershamsi, and K. Behzadian, "WATER RESOURCES DEVELOPMENT : Estimation of Peak Outflow in Dam Failure Using Neural Network Approach under Uncertainty Analysis 1," vol. 42, no. 5, pp. 723-736, 2015.

[15] Y. Xu and L. M. Zhang, "Breaching Parameters for Earth and Rockfill Dams," J. Geotech. Geoenvironmental Eng., vol. 135, no. 12, pp. 1957-1970, 2009.

[16] S. Uni., "National Performance of Dams Program," Stanford Uni., 1994.

[17] V. Singh, "Dam Breach Modeling Technology," Kluwer Acad. Bost., 1996.

[18] Z. W. R. A. (ZWRA), "Log of the August 1975 storm event in Zhumadian," ZWRA, Henan, China (in Chinese), 1997.

[19] H. W. R. A. (HWRA), "The August 1975 catastrophic flood disaster in Henan," Yellow River Water Conserv. Zhenzhou, China (in Chinese), 2005.

[20] Tex.stackexchange.com, "Drawing Back Propagation Neural Network," 2016. 
ICGRE 169-10 